\title{
5. From Medicine to Morals, and Back Again? The Changing Perceptions of 'the Drug Problem' in Norway since 1965
}

Paul Larsson

This article will deal with how the public and political discourse has changed in Norway during the last five decades concerning the 'the drug problem'. The basic idea is that these changes are related to the ways the drug problem is perceived and presented in the public discourse and official publications. The reasons for these changes in perception are related to factors such as external pressure to implement penal regulations of the field but also changes in youth culture and how it is conceived by the public, media, and the political elite (NOU 2019: 26; Ot.prp nr. 5 I97I72; Skretting 2013; St.meld. 66 I975-76).

Hauge (2009) and Lind (I974) stated that, until the mid I960s, Norwegian state officials implemented the international laws concerning drugs, such as the single convention, without giving them too much attention. Drugs were not seen as a substantial problem in Norway, at least not a crime problem, so the effects or relevance of these laws did not cause much worry. The main strategy towards the drug problem from the I930s until the early I960s was health oriented (Lind I974; Pedersen 2020). Drugs were not a hot topic in the press or in politics, they was mainly regarded as a medical problem for experts to deal with. The first two police officers working part-time with drugs were appointed in the Oslo PD in I965. This relaxed approach was to change dramatically in the years to come. One of the most interesting features of this process of penalization was the creation of the drug user as deviant

\footnotetext{
How to cite this book chapter:

Larsson, Paul. From Medicine to Morals, and Back Again? The Changing Perceptions of 'the Drug Problem' in Norway since I965. In: Retreat or Entrenchment? Drug Policies in the Nordic Countries at a Crossroads, edited by Henrik Tham, I03-I 27. Stockholm: Stockholm University Press, 202I. DOI: https://doi.org/IO.I6993/bbo.e. License: CC BY 4.0.
} 
and criminal, and the development of new and expanding categories of crime. Drug users used to be conceived as a health problem, in need of care and assistance. The criminalization of drugs was a move from medicine to morals. The normal reaction towards drugs changed to one of police involvement, sentence - normally a fine - and an attached stigma. In line with classic stigma theory, deviance is not something that originates from the person itself or the act, but instead our way of reacting to certain acts under certain circumstances by certain people (Franko 2020). The criminal drug addict became associated with youth with certain traits - long hair and often with social, mental, and health problems. As Lind points out as early as I974, the ones who came to be labelled as drug addicts and rounded up by the police were not the average youth experimenting with drugs, but a sad representation of marginalized segments of Norwegian society.

Table I 2 shows the growth in cases investigated from I968 to I998. There are no other forms of reported crimes that are even close to this rate of expansion. The numbers continued to grow until 2013, when they peaked at an all-time high with more than 47,000 cases reported (Table I3). ${ }^{19}$ Since this time there has been a marked decline, as with other forms of registered crime. The numbers show the most dramatic increase in the I990s.

Table 12. Investigated drug cases, I968-I998.

\begin{tabular}{|l|r|r|r|}
\hline year & \multicolumn{1}{|c|}{ total } & \multicolumn{1}{c|}{ drugs } & \multicolumn{1}{c|}{ theft } \\
\hline I968 & $5 \mathrm{I}, 830$ & 20I & $4 \mathrm{I}, 933$ \\
\hline $\mathrm{I} 973$ & 86,992 & $\mathrm{I}, 262$ & 73,795 \\
\hline $\mathrm{I} 978$ & $\mathrm{I} 05,263$ & $\mathrm{I}, 6 \mathrm{I} 7$ & $88, \mathrm{IO} 8$ \\
\hline $\mathrm{I} 983$ & $\mathrm{I} 59,598$ & 3,793 & $\mathrm{I} 33,052$ \\
\hline $\mathrm{I} 988$ & 220,338 & 6,229 & $\mathrm{I} 8 \mathrm{I}, 3 \mathrm{I} 4$ \\
\hline $\mathrm{I} 993$ & 248,203 & $\mathrm{II}, 739$ & $\mathrm{I} 94,907$ \\
\hline $\mathrm{I} 998$ & 292,233 & $30,29 \mathrm{I}$ & 206,786 \\
\hline $\mathrm{I} 998: \mathrm{I968}$ & 5,6 & $\mathrm{I} 50,7$ & 4,9 \\
\hline
\end{tabular}

Source: Haslund (I999).

I9 Table I 2 represents investigated cases while I 3 deals with reported cases. The numbers of reported cases will be higher than those investigated since cases will be dropped for different reasons. 
Table 13. Reported drug cases, I993-2017. ${ }^{20}$

\begin{tabular}{|l|l|l|l|l|l|l|}
\hline I993 & 1996 & 2001 & 2004 & 2009 & 2013 & 2017 \\
\hline I2,7I4 & 26,532 & $46,25 \mathrm{I}$ & 37,259 & 39,280 & 47,286 & 33,585 \\
\hline
\end{tabular}

Source: Reported Crimes. ${ }^{21}$

Not only did the number of cases and police resources increase, so too did the severity of punishments and sentences. Christie and Bruun (I985) document the developments in the scales of punishment, from a maximum of two years imprisonment in I964 to $2 \mathrm{I}$ years in 1984. This raises two questions: what can explain these numbers? How can we make sense of them?

The common response to this growth in numbers is that they simply reflect the developments of the drug problem. 'Look at these numbers, something must be very wrong in society when we create harsher laws but numbers still keep rising.' The answer to this claim has often been that we need still tougher laws and more police resources to scare off traffickers, pushers and users.

Another response is that the numbers primarily mirror the control activity in the field. The more police and customs resources that are used, the higher the number of cases detected. In this perspective, drug-related crimes are a more or less inexhaustible resource where police 'round up the usual suspects'. This is pointed out by Lind (1974) when she documents that approximately $5 \%$ of the cannabis users in Oslo were apprehended by the police. In general, users reflected the general population, however the ones caught more often had personal, social, and medical problems. They confirmed the stereotypical image of the 'drug addicts'.

We know from data on self-reported use that there was a clear increase in drug use in the r970s (Haslund I999). This increase was not in any way close to the growth in the number of investigated cases. The alarming development in the r990s, with an increase in reported cases of approximately $300 \%$, cannot be

${ }^{20}$ In the period 1993 to 2013 , the percentage of drug cases compared to all recorded crimes increased from $5.5 \%$ to I $8 \%$. There has been a drop since $20 \mathrm{I}_{3}$, not only in drug reports but all reported crime (Larsson).

2г Tabell 4 Lovbrudd anmeldt, etter type lovbrudd. I99I-200I (ssb.no). 
explained by the rise in use alone - the main explanation is related to policing. The period was characterized by stability and a sharp rise in the use of ecstasy and pills at the end of the century, often linked to the techno and rave culture, which later went down again (Stene 2003).

When it comes to sentencing, Hauge (2008 and 2015) documented that the peak came early, in the r980s. Since that time there has been a move from imprisonment towards fines for users. Today, fines dominate (Larsson 20I I; NOU 20I9: 26). Sanctions against traffickers and dealers are still severe and disproportionate compared to the levels of punishment for other crimes in Norway (Träskman 2012).

\section{Towards a Moral Panic?}

Christie's article, 'Long haired life-style' (I968), described the reactions of panic by parts of the establishment concerning the small groups of strange looking, highly visible youngsters in Oslo at the end of the I960s. As researchers in the field have pointed out, drug use is nothing new, but the visible presence of long-haired, weirdly dressed youngsters smoking cannabis, combined with a growing interest in drugs among the public, media, and politicians, created an atmosphere verging on panic (Skretting 20I3). As Lind (I974) pointed out, there was indeed a growth in the use of some substances from the mid I960s, but the way the media presented this blew it way out of proportion. Drug use was depicted as epidemic and youngsters could get hooked after more or less one puff of the pipe. The result was not only wasted lives and early death but also a threat to our morals, society, and culture. 'The point is that the development only goes in one direction, towards moral and physical decay, loss of sense of reality, a dissolution of the self ... Sadly there are thousands of examples that just one little try might lead to dependency and damage done ....22 (Lind I974:39). The debate and the reactions seem to have all the basic ingredients of a moral panic, as Stanley Cohen described, with a clear enemy, a threat to society and norms, a black-and-white, exaggerated, and one-sided

${ }_{22}$ These arguments are from one of the first interpellations on drug problems in the Norwegian Parliament in 1967. 
depiction of the problem in media and strong societal reactions (Cohen I972/2009). Drugs shifted from medicine to morals. The level of punishment was raised. The main legal argument then, as now, was a general preventive one - that the threat of punishment would scare off users and the wider normative effects it would create (Christie \& Bruun I985). But we also see clear traces of another penal logic - punishment as social defence (Flaatten 20I4). The drug situation at the time was described by many as an epidemic ${ }^{23}$ wildfire, with strong measures seen as appropriate to stop the destruction of the youth and save society.

Use and possession was criminalized in I965. As mentioned, Legemiddelloven of I964 came as a follow-up to the UN Single Convention and was adopted before the 'new' drug problem came to Norway. In accordance with the Convention, the law was aimed at the illegal possession and sale of drugs, and contained no explicit provision for use. Prohibition of use, however, was included in the 1965 regulation, and was used as a legal basis to impose penalties for use in the first drug cases that came to court this year (Skretting 2013). Lind (1974) points out that the legal status of punishment for use was disputed. The dispute ended with a Supreme Court decision in favour of using punishment in May 1967.

The end of the I960s was a time of change and flowering of counterculture. The use of different substances was often associated with radical changes and seen as a general threat to established society by more conservative elements of society. It is pointed out that Nixon's war against drugs was more a war against blacks and radical groups (Hari 20I5). By chasing drug use among certain visible groups the police activity had aspects of 'cleaning up' elements seen as threatening, unwanted, and deviant.

An interesting detail is that this more or less coincided with the removal of the vagrancy paragraphs that made consumption of alcohol in public illegal in Norway (the vagrancy law). This highly discriminating law, which more or less without exception punished poor drinkers, was abolished in 1970 (Mathiesen I975). The public was waiting for the streets to overflow with drunkards.

${ }_{23}$ The Norwegian director of health, Karl Evang, and the Swede Nils Bejerot were among the proponents of the idea of an epidemic perspective. 
Instead, what happened was that the police changed from pursuing old-sailors, helpless drunks, and vagrants and started to catch a new group of deviants, the long-haired youths associated with drug use.

\section{0s and Early 1980s - Hunting the Drug Shark!}

The repeated raising of the level of punishment during the I970s and I980s was not primarily aimed at the drug users. ${ }^{24}$ Instead, the cynical Mr. X or drug shark became the main enemy. This started in 1972 with the raising of the maximum punishment for drug related crimes to Io years. We were told there was a drug industry - we are not talking of the legal, multibillion-dollar drug industry - controlled by cynical criminals with immense powers and riches. In Nordic language they were known as bakmenn, literary men behind the scenes. These facilitators speculated in turning people into drug slaves to reap even higher profits. The goal of the police was to 'take out' these sharks, and Denmark was the first Nordic country with its own police force dedicated to this goal. ${ }^{25}$ Arresting these villains would stop drugs from entering the streets and deter others joining the trade. They were nothing but plain killers peddling their poison on kids and turning them into slaves of 'lifelong torture'. ${ }^{26}$ Severe punishment would make it less 'attractive' for drug traffickers to search out the Norwegian market and would have a deterrent effect (Lind I974; Skretting 2013). Therefore, heavy penalties and wide police powers were appropriate and needed.

The problem with this approach, based on commonly shared beliefs, was that it had some basic flaws. Drug markets are not controlled by a handful of people. Instead, they are flexible and

${ }_{24}$ The belief in the deterrent effects of punishment towards users may have been a constant, but the idea of how punishment was having such an effect has varied. There have been periods when a 'scared straight' idea has been dominant, with the threat of police action seen as keeping kids away. Today, however, there is a belief in the normative effects of punishment, usually described as 'sending the right signals' (often underlined by the police) and as a 'last threat' in preventive policing (described below).

25 Statsadvokaten for særlig økonomisk kriminalitet, known as bagmandspolitiet, was established in 1973 .

${ }_{26}$ From Ot. tidende nr. 49, sak, nr. 4, I967/68 (Lind I974: 50). 
highly adjustable. The police and customs confiscate tons of cannabis, heroin, cocaine, and other drugs, but there are always plenty more and the market also adjusts with the production of new drugs, often more dangerous than the original ones (Bewley-Taylor 20I2; Nutt 20I2). The level of punishment seems to have a marginal effect on smuggling, production, and consumption (MacCoun \& Reuter 200I; Paoli, Greenfield, \& Reuter 2009).

Once in a while, a drug baron controlling at least parts of the drug trade in some countries pops up (Zaitch 2002). But research has documented, at least since the time of Bødal (I982), that the 'sharks' that end up in prison are users themselves, with few exceptions, often with dire problems. They look confusingly similar to the ordinary prisoner - people with multiple social, health, and medical problems.

Even more depressing was the fact that removing actors that seemed to be big time players of central importance made little difference at all (Woods 20I7). Arresting a trafficker (Gjermund Cappelen, known as GT) who admitted to having smuggled 20 tons of hash to Norway in a 20 -year period made no visible difference to the market. The number of big drug cases in Norway before 2000 was very few. Still today, $97-98 \%$ of the cases handled by the police are concerning use, possession, and small-time dealing (Larsson 20II).

\section{Mid 1980s to 2000 - Cracking Down on the Users, 'Stress Policing'}

The I990s saw an explosion in the number of reported drug cases that is hard to explain (Stene 2003). There might be different factors contributing, such as changes in registration practices and drug use, but most of the increase seems to be connected to police activity. So, what happened? At a time when reported crimes started to drop, the drug cases sky-rocketed while the level of consumption increased moderately.

The State Institute of alcohol and drug research have asked youth in the age $\mathrm{I}_{5-20}$ years if they ever have used cannabis. The proportion giving a yes answer increased from 5 to 18 percent in the 
period I986-I998. In the same period the numbers of investigated drug crimes increased by seven times.

(Haslund I999)

Some of it might have to do with new routines for reporting crimes and the implementation of a new digital system in the police (Ellingsen 200I). But there must be other factors. One such factor is priority and resources allocated to the police. Another might be that the police were better organized, the Norsk narkotikapolitiforening (NNPF), a mighty organization for the Norwegian drug police, was established in 1994. The police were impressed by the Danish 'uropolitiet' (stress police). Both the Danish and the Norwegian uropolitiet worked in the streets in plain clothes by infiltration, provocation and other 'creative' methods (Jensen 2015). Money was never a problem when it came to policing drugs in this period. No political party would cut the budget of the drug police. The work was seen as saving lives and of high importance.

Police got more professional and specialized in the drug field. There have since been courses and training programs in how to detect narcotics and substance use, with the number of drug sniffer dogs also having increased.

This coincided with the implementation of New Public Management ideals in the police force. With new management ideals there was a pressure to register more activity (Lomell 20I 8). Police officers are quick to point out that this created a pressure to register cases easily solved and with high clear-up rates. Therefore, there might be evidence that a substantial part of the increase seen was a result of the drive towards cooking the books for better scores (Reiner 20I0). Drug numbers are well known fixers of police statistics, with an extraordinarily high clear-up rate and a short processing time. In many countries, drug statistics are not included in the general crime statistics for this reason, ${ }^{27}$ but not in Norway. There are plenty of examples of the unintended consequences of the stressing of certain management goals (Wathne 20I5). One well-documented example was the manipulation

${ }^{27}$ Example is the Crime Statistics of England and Wales. https://www.ons .gov.uk/peoplepopulationandcommunity/crimeandjustice/bulletins /crimeinenglandandwales/yearendingmarch20 I9\#overview-of-crime. 
of drink driving tests by the Swedish police by blowing the tests themselves, ${ }^{28}$ or getting the correct numbers in other ways (Granér 2004). Doing the real test could be hazardous - if they actually caught a drunk driver there was lots of paperwork, so the best thing would be to do the test in low-risk areas and at times when there was less chance of drunk driving.

\section{The Increased Focus on Organized Crime}

A major shift occurred in the mid I990s when organized crime was introduced as a major threat (Larsson 2018). Serious drug crimes were re-labelled. For many police officers, organized crime was more or less synonymous with drug crimes. This is still reflected in priorities and resources used and in what the police register in their intelligence files (Eidet 2019). There was a move from policing the streets towards more analytical approaches based on intelligence work (intelligence-led policing) and the use of hidden and coercive methods, such as wiretapping, infiltration, and the use of informers (NOU I997: I 5; NOU 2009: I 5). A new group of police specialists and experts evolved with more analytical skills. They worked in more pro-active ways to build cases (Fyfe, Gundhus, \& Rønn 2018). In the words of Murji (1998), there was a move from low-level to high-level policing. Resources were diverted from street work to catch importers and traffickers of drugs. Working on the streets with 'stress policing' used to be of high status in the police, however, now there has been a move towards experts in analysis and intelligence-led policing (Larsson 2015, 20I8).

Policing drugs has been the spearhead of substantial changes in policing for the last 50 years (Sheptycki 2000; Larsson 20I4). Some of the most important changes are a growth in international policing, a wider use of coercive methods, more effective co-operation with other agencies of policing, the development of intelligence-led policing and analysis, new investigative methods, and a growth in the numbers of civilian experts in the police

${ }_{28}$ By blowing the tests themselves, they avoided catching any drunk drivers, and so also avoided all the extra paperwork and other nuisances that went with this. 
(Larsson 20I8). Policing drugs has been one of the most central contributors to changing the role of the police and introducing new methods that have implications for society far beyond the police force itself.

\section{The Sick Drug Addict and the Problematic Youth}

Norway have been described as one of the hawks in the drug policy field. This has only been a partial truth (Bewley-Taylor 20I 2; Skretting 2013). There have always been groups of users treated in more health-oriented ways, but the health focus has become more visible since the turn of the century.

Norway have had treatment facilities established for drug users since the early I960s, but they were for 'traditional users' - doctors, health personnel, and patients with dependency problems (Lind 1974, NOU 2019: 26). A wider move towards a health approach came as a result of the HIV/AIDS epidemic of the I980s. Harm reduction now became a central term (Bewley-Taylor 20I2). The spread of $\mathrm{LAR}^{29}$ to a substantial number of heroin users and the opening up of injection rooms in 2004 are examples of a turn towards health (Olsen 2020). For a short period in 2004, the Police Chief of Oslo and the minister of Justice at the time, Dørum, declared that it was not the task of the police to chase sick and tired drug users, resulting in falling numbers of reported crimes. However, subsequently, things more or less returned to normal. ${ }^{30}$

The tired heroin user on the street has gone from being a prime example of 'the usual suspect', dangerous criminal, and police property, to being seen as sick and in need of help and rehabilitation. This process has taken years and one should not under-

${ }^{29}$ LAR is short for Legemiddelassistert rehabilitering. It is the use of opioid treatment for drug users, usually heroin users with a long history. Also known as substitution treatment.

${ }^{30}$ https://www.aftenposten.no/osloby/i/5E67 I/doerum-og-lae-lover-aa -ikke-jage-de-narkomane. The message was repeated by the General attorney in 20I4. Police shall not chase worn-down drug users, but prioritize serious crimes. https:/www.dagsavisen.no/nyheter/innenriks/politiet-skal -ikke-lope-etter-slitne-narkomane-ı.278016. 
estimate the roles of Nini and Thorvald Stoltenberg ${ }^{3 \mathrm{I}}$ in giving a face to the user and the relatives. Thorvald was one of the first top politicians openly supporting the decriminalization of drug use, and the leader of the Stoltenberg Commission ${ }^{32}$ and member of the Global Commission on drug policy. The high numbers of drug-related deaths have, for the last decades, been a fly in the ointment and embarrassment of the Norwegian welfare system. The highly visible, tired, and sick opioid addicts in the main streets and parks of Oslo and Bergen have been bad publicity for the world's best country, ${ }^{33}$ and a thorn in the side of local politicians and businesses.

Considering the population of 5.4 million, the numbers given in Table I 4 are high. The numbers were low until the end of the I 980 . There was then a sharp rise, peaking in 200I. Since 2003 the numbers have fluctuated round 275 a year. It is interesting to

Table 14. Drug-related deaths in Norway. ${ }^{34}$

\begin{tabular}{|l|r|r|r|r|r|r|r|}
\hline Year & I985 & I995 & 2001 & 2007 & 2013 & 2016 & 2020 \\
\hline Deaths & 45 & I43 & 405 & 275 & 234 & 275 & 324 \\
\hline
\end{tabular}

Source: Amundsen (2015); Narkotikautløste dødsfall 2020 - FHI.

${ }^{31}$ Thorvald Stoltenberg was former minister of foreign affairs and father of Jens Stoltenberg, prime minister and now General secretary of NATO. Nini was the daughter of Thorvald. She had a career in media before she became addicted to heroin. She was open with her problems and told the tale of the hard life of being a stigmatized addict. Thorvald got engaged in the drug case and was a strong believer in change. Nini died in 20I4 and Thorvald passed away in 2018.

${ }^{32}$ https://www.regjeringen.no/globalassets/upload/hod/rappomnarkotika _nettversjon.pdf.

${ }_{33}$ I use this term with a slight potion of irony for 15 years Norway has been on the top of UNDPs list of the best nations to live in. Human Development Reports (undp.org).

34 Drug-related deaths are divided into three main categories: poisoning accidents $(72 \%)$, suicides $(20 \%)$, and mental disorders and behavioural disorder in connection to drug use. $83 \%$ of the deaths are related to opioids, with 'other opioids' (morphine, kodein, and oxycodon) at $3 \mathrm{I} \%$, heroin at $20 \%$, synthetic opioids at $18 \%$, and methadone at $14 \%$. There are dark figures and the numbers of suicides are generally considered to be higher than what is reflected in the statistics (Narkotikautløste dødsfall 2019 - FHI). 
note that these numbers seem like a mirror of the rise in reported drug cases (Table I3).

Skretting (2013) describes the Norwegian policy as basically schizophrenic - there are elements of a strong belief in punishment and severe penalties, but also in rehabilitation and health care. ${ }^{35}$ Norway has a maximum penalty for serious drug crimes of 2I years of imprisonment. What is conceived as a serious case in a Norwegian context, however, might be viewed as small fry in The Netherlands, Spain, or the UK. ${ }^{36}$ This might not be as schizophrenic as Skretting claims, but instead mirrors that some groups are labelled as 'deserving' drug addicts and patients, while others are seen as a threat and so are suitable candidates for deterrence and punishment. The schism also reflects the different professions operating in the field and their perspectives. Social workers, police, and health personnel will perceive the drug problem and its solutions in different ways. The drug question is like the well-known story of the blind man and the elephant - dependent on what part you see or feel, it will appear as a different animal. The so-called symptom theory, that drug use was basically seen as a symptom of problems related to the social, health, and economic sphere, was officially established in I976.37 This perspective underlines the social causes, while over the last decade we have gone a long way towards defining drug use in medical and health terms. We have moved from symptoms to illness. In this way, we have also gone from social to more individual causes as the main explanations. This might also reflect that the ones 'defining the solutions'

35 'Abuse is increasingly interpreted in a disease perspective, harm reduction has become more important, while people with drug problems are referred to as addicts. In this way, one could say that Norway is in a situation where we have developed a "schizophrenic" view of the drug problem, by on the one hand stressing the health aspects of abuse, while on the other hand seeming to be trapped in legislation, with severe penalties for drug offenses, which prevents a softening up if this is seen as appropriate' (Skretting 20I3, translation Paul Larsson).

${ }^{6}$ One example, 8 okg of cannabis is the limit for what is seen as a serious crime concerning smuggling of cannabis. When it is defined as a serious drug crime the maximum sentence is $2 \mathrm{I}$ years. $80 \mathrm{~kg}$ of cannabis in the Netherlands, Spain or UK will not be treated as serious drug trafficking.

37 St.meld. nr. 66 (I975-76). 
have moved from social workers to the medical and health care professions.

The cornerstone of policing drugs in Norway for the last decade has been coined preventive work. The last action plan by the police concerning drugs underlined the need to reduce the availability of drugs on the street and the recruitment to drug use (Politidirektoratet 20IO; Larsson 2015). This plan is characterized by low policing and street work, the remnants of stress policing. For some reason, the policing of import and trafficking is not mentioned in the action plan - it might be because this is seen as combating organized crime. Another plausible explanation of this omission might be that the plan is not written for experts but for the local patrolling officer.

The plan points to the importance of police combating availability of drugs on the streets, hoping to reduce demand, and use. The means of 'how to achieve this' are well known, it is a combination of cracking down on known users (on the street), by information to the public, and the use of surveillance. The plan is rather vague when it comes to describe the practical aspects of these approaches.

The last decade new preventive strategies aimed at young drug users have become fashionable. They are named the dialog of concern $^{38}$ (bekymringssamtale) and youth and drug contracts (NOU 20I9: 26). These are formally based on free will and consent ${ }^{39}$ of the youngsters, and are presented as help. These reactions can be supplemented with the use of mediation in a Conflict Resolution

$3^{8}$ The dialog of concern has been developed by Norwegian police. It is a formalized dialog that the police will conduct with youth that have committed a crime or those who are in a situation that the police believe makes it likely they will commit a crime. It is for youth under I 8 years and is also primarily based on free will. Often the police will contact the parents to inform them about the situation. The effects of this alternative have not been documented by research (Lie 2020). Politiets bekymringssamtale - NUBU.

39 There is a discussion about whether or not these measures are actually perceived as being of free will, as the pressure to join and the control in these 'alternatives' are such that it is openly questioned if they are for the good of the youth. There has so far not been any study of the effects of these alternatives. 
board. These 'preventive measures' are backed by the threat of punishment and a heavy use of urinal tests (Lien \& Larsen nd _PUB_Flinkiser_og_dropouts__orig.pdf (rus-ost.no)). They have a duration of eight months and the youngsters are obliged to attend talks with a nurse on a regular basis. Drug contracts are seen as suitable for youngsters and a low-threshold reaction. Even if the police label these measures as preventative, they view them as dependent on the threat of punishment. This, together with the normative argument (below), is among the main arguments against a decriminalization of drug use by the police and representatives of the political parties $\mathrm{KrF}$ (Christian Democrats), FrP (The Progressive Party, a populist party), and, to a certain extent, the AP (Social Democrats).

We are now in the rather strange situation where there is little resistance against a decriminalization and relabeling of heavy drug users from dope fiends to patients. At the same time, young experimental users will still be criminalized for the sake of the belief of punishment as prevention (Møller 20II). These preventive measures have not been evaluated for their effectiveness by any researchers. This is an echo of the Penal Code Commissions (Straffelovrådets) report from I967: 'The fact that unjustified use is punishable must also be presumed to be deterrent to some of those who might otherwise be willing to experiment with drugs.' (Skretting 2013).

There is still the traditional belief in the symbolic normative value of punishment, which says it is wrong to decriminalize drug use because it sends the 'wrong signals' (Hauge 2008). Decriminalization is described as synonymous with the state approving drug use, however, strangely, the same argumentation is rarely used concerning alcohol or tobacco.

\section{From Punishment to Health}

Christie and Bruun (I985) described drugs as a suitable enemy. Suitable enemies share some characteristics making them ideal targets for societal reactions. Drugs have, for the last five decades, been a focal point not only in criminal politics but also in politics in general. A minority have, until recently, been openly questioning 
the policy and the general rationality behind it, but the majority have supported the status quo. ${ }^{\circ}$ But things are changing.

Slowly, the climate of discussion and action seems to have changed. New voices can be heard, most notably, the voices of the users themselves. Debates are still heated and fronts can be hard, but there are now a wide variety of alternative views expressed. The field flourishes with all types of organizations and pressure groups, drug users fighting for their rights to use drugs legally; self-help groups; movements trying to establish drug use as a human right; some working for the safer use of drugs and others for treatment. There are a wide plethora of associations supporting criminalization and the use of penal sanctions. The most important event was probably when, in December 20I7, the Norwegian parliament declared that there was a political majority for a change $^{4 \mathrm{I}}$ in the drug policy - from viewing drug use as a penal matter to defining it from a health perspective. Minister of health Bent Høie was crystal clear when he declared:

Drug addicts shall receive healthcare and respect - not punishment and condemnation. We are now starting on the task of changing the Norwegian drug policy and the attitudes towards fellow humans that struggle with drug dependency. (https://www.regjeringen.no /no/aktuelt/utvalg-skal-forberede-ny-rusreform/id2594838/)

There was advice from the politicians to the committee working on the whitepaper of the drug policy was clear, look to Portugal. In criminological and penal law terms the advice was to move the reactions on drug use from penalization towards prohibition with civil penalties, or decriminalization (Bewley-Taylor 20I2). What this meant in practical terms was rather open. Should all types of

$4^{\circ}$ There has been some voicing of other perspectives. One is the Penal law commission that proposed a decriminalization of the use and possession of drugs and a reduction in the levels of punishment (NOU 2002: 4). The reaction from the Minister of Justice was to put this proposal 'in the drawer', commenting that the time was not ripe for even discussing such changes in Norway.

${ }_{4 \mathrm{I}}$ Three parties go against this: FrP (Populist party), SP (Centrum party) and $\mathrm{KrF}$ (Christian democrats). FrP is split - the youth organization have for years been pro-legalization. 
use be decriminalized? There is a big difference between worndown heroin addicts, casual users of 'party dope' and youngsters experimenting or casual smokers of cannabis. Should it cover use of all kinds of drugs or just 'softer' drugs? What would help users and how should it work? Should there be civil sanctions, or even penalties for users who would refuse help and treatment? What is the role and tasks of the police in such a system? How would such a reform affect the working conditions and methods of the police? Parts of the police in particular aired scepticism on the whole idea of such a reform. Three days before the report the Police Director published a media article with the suggestive title, 'I am worried about the youth', showing her position against the reform..$^{4^{2}}$ She was anxious that a reform would result in a growth in the number of young users and moral decay, and believed punishment was needed, claiming the current policy of punishing users a success. These arguments, similar to the ones used in the I960s, came to be central in the weeks to come. ${ }^{43}$ But the stunt mainly backfired and was criticized as being built on a lack of knowledge and reflecting a moralistic stance. ${ }^{44}$

On the I9th of December, 2019, the report, Drug-reform - from punishment to help, was released (NOU 2019: 26). For those nervous about a toothless report, there was no need to worry.

The proposals were as follows: a decriminalization of the use of all types of drugs; using, buying, and possessing a certain amount of drugs for own use would be prohibited, but not a crime; and the sanction would be to meet for a board (rådgivningstjeneste) of municipal advisers. Users skipping such 'advise' should not be met with formal sanctions. The proposal when it came to the limits of drug possession was split. The basic argument was that the limit should be such that the users did not have to buy drugs every day, in this way reducing their contacts with the drug dealers

${ }^{42}$ https://www.nrk.no/ytring/jeg-er-bekymret-for-ungdommen-I. I 482 I 890 .

43 And also in the final rounds of the making of the new law in the spring of $202 \mathrm{I}$.

44 https://www.minervanett.no/benedicte-bjornland-rusreform/plag-oss -ikke-med-kunnskap/350229. Spring and summer of 202I the Police Director was criticized for airing the views of the private organisation NNPF (Norwegian Drug Police Organisation) and mixing roles of the police and a pressure group strongly against reform. 
on the street. At the same time, the police pointed out that the limit set would give a clear signal to the pushers of how much they will be able 'to get away with'. There are big differences in use, which reflect the users drug history. The majority proposed a limit of 5 grams of heroin, cocaine, and amphetamine, and I 5 grams of cannabis. The minority had limits of I grams of heroin, cocaine, and amphetamine, and 5 grams of cannabis. ${ }^{45}$ The report also proposed limiting the use of intervening police practices towards users. ${ }^{46}$

The main message of the report was the move from punishment to help (Pedersen 2020). In some ways this was a return to the policy in place before 1965 . The report was $4 \mathrm{I} 2$ pages long, and the scope was wide. The reactions on the report were primarily positive, but there was, as seen above, also critical voices. The most debated issue was 'the youth problem'. Fear of an increase in use and a moral decay among the youth is probably the aspect most hotly debated, even though the report analyzed these topics in detail and showed there was little reason for alarm. The lack of sanctions for the ones not meeting for the advisory board was another debated aspect. ${ }^{47}$ At this point, the report takes a different stance than that practiced in Portugal, where they have a wide spectre of sanctions, even if they are rarely used. Youngsters will not go to a consultation if there is no threat of a sanction or punishment, critics pointed out. The report argues, from a principal point, that when they do not propose sanctions, 'In the Committee's view, this would be unfortunate (the use of sanctions) in the light of the division of roles between the police and the health and welfare services and the trust between the individual and the public assistance services' (NOU 2019: 26).

The future of the drug reform is, at this time (March 202I), still uncertain. There have been major shifts in Norwegian politics

45 This was changed and reduced during the process of making the law (Prop 92.L 2020-202I) to 2 gram of heroin and Io gram of cannabis.

${ }_{46}$ This is a field with exceptionally wide police powers in Norway (Larsson 2OI4).

47 This was changed in the process of making the law. It was proposed that a fine of $2400 \mathrm{nkr}$, that is approximately $€ 230$, could be given if the person did not attend the meeting. 
since the release of the report that change the whole debate. The reform had a political majority because the ruling parties (Høyre, $\mathrm{KrF}$, Venstre, and FrP) had decided at the Granavolden conference in 2019 to implement it. This decision was the result of tough political wrangling, as $\mathrm{KrF}$ and $\mathrm{FrP}$ were sceptical of the reform. The reform has been the baby of the liberal conservative party (Venstre) and Høyre (Conservatives). In January 2020, FrP (Liberal Populist Party) left the Government, the break officially a result of an Islamic State supporter being brought back to Norway from Syria with her two children for medical treatment. To get a majority in Parliament, the Government had to rely on FrP, who has now been openly critical. Today, the reform is dependent on the support of the Social Democrats, who are divided in their views. The Norwegian Labour Party (AP) are the ones that decide the destiny of the reform. ${ }^{48}$

\section{Drug Reform as a Mixed Blessing}

The slow progress towards drug use being perceived mainly as a health problem should come as no surprise - it has been in the making for quite a while. But this is far from stating that policies are on the way towards legalization. It was not in the mandate of the drug reform committee to think 'outside the box' about what to do with the sale and handling of drugs. Alternatives such as medical marihuana and state-regulated sale of drugs in coffee shops are rarely openly debated in Norwegian politics. Punishment is seen as necessary to restrict the trafficking and use. ${ }^{49}$ Sentences in drug cases are still unproportionally severe. The idea that punishment works in restricting the volume of drugs in society, without taking into account the costs of this, are firmly held. Punishment is seen as necessary to deter new users, as expressed in I967, while addicts are seen to need help instead of punishment. The problems

${ }^{8}$ The reform did not pass. In May 202 I AP decided not to support it. It was election year for Parliament and AP expressed the view that they would develop their own drug reform.

49 There have been some representatives of Venstre, and hard-core liberalists in FrP and among the youth parties, that have argued for legalization. https://www.aftenposten.no/norge/politikk/i/e8XoQR/unge-venstres -kampanje-for-legalisering-vi-deler-ikke-ut-rusmidler; https://www.vg.no /nyheter/innenriks/i/P.3ROd6/frp-forslag-om-statlig-salg-av-cannabis. 
with this neat picture are that the majority use drugs in recreational ways and don't get sick or addicted (Hauge 2009; Møller 20II; Nutt 20I2). Dependency, however, is a highly problematic concept in itself (Bramness 20I8).

Maybe we have finally come to a point where other problems seem to attract more attention than drugs. The police have a wide array of 'suitable enemies' today, so drugs may seem to fall out of the picture - the immigration crisis, trafficking, cybercrimes, the war on terror, and environmental problems are examples from a long list ${ }^{50}$ (Franko 2020).

The number of countries and states that have now decriminalized and even legalized the use of one or more drugs has increased. Many of these are states we often like to compare ourselves with. At the same time, there now exists research that shows that this does not end in chaos, an explosion in drug use, and a doomed youth (NOU 2019: 26). Norwegian politics have always been influenced by international trends - we have a tendency to follow, which is also seen in the area of drugs (Hauge 2015). As described in this chapter, the field has always been open to a wide array of approaches and perspectives. Maybe we are at a tipping point where it is time to shift from an approach that, to a large extent, relies on the belief in deterrence and punishment towards a more health-oriented approach.

But what does this mean? Such a development might be a mixed blessing. To depict the drug user as dependent and sick is not only to put him in a position where he might get help, it is also a way to disempower, to introduce new modes of control and discipline that might be more coercive and just as intrusive as what we have now. The wide array of so-called preventive measures, presented as soft alternatives, normally rely on the extensive use of control measures, such as urine control in youth contracts (NOU 20I9: 26). Police and health personnel cooperate. ${ }^{\text {I }}$ Youths on such contracts often experience these measures as degrading and

${ }^{\circ}$ https://pst.no/alle-artikler/trusselvurderinger/nasjonal-trusselvur dering-2020/.

${ }_{51}$ Not always - in some places the health workers do not want to take part as controllers taking urine tests. In these instances, private firms have taken the role of the health workers. 
demanding. ${ }^{52}$ These alternatives are presented as 'free to choose', but the stick is there if you do not cooperate. Encounters between youth and police when it comes to enforcement of the contracts can be highly unpleasant. The rights of users on such alternatives are in a totally different league than if they had been sentenced in court. These youth are not sick, what they have committed are more often minor acts, such as smoking cannabis. These dilemmas have been addressed in the drug reform report. The alternative presented in the report, the advisory board, might be a better solution. Anyway, its main function is to give advice and channel the problem users to the help system. There is political pressure to sneak in punishment in the reform by differentiating between the types of users and by using waiver of prosecution ${ }^{53}$ in cases with adult drug users. It is pointed out time and again that the reform is dependent on substantial economic support to build up a working system of help and support, as is the case in Portugal (Hughes \& Stevens 20I2). Anyway, we should be aware of the dangers of re-labelling drug use, this might be a mixed blessing.

\section{References}

Aftenposten (2004). 'Dørum og Lae lover å ikke jage de narkomane.' https://www.aftenposten.no/osloby/i/5E67 I/doerum -og-lae-lover-aa-ikke-jage-de-narkomane.

Amundsen, E. J. (2015). Narkotikautløste dødsfall, SIRUS Rapport 2, 2015 , Oslo.

Bewley-Taylor, D. R. (2012). International drug control. Consensus fractured. Chicago: Cambridge University Press.

Bødal, K. (I982). 350 narkoselgere. Oslo: Universitetsforlaget.

${ }_{52}$ https://www.moss-avis.no/nyheter/nyheter/mener-politiet-misbruker -narkotika-makt/s/2-2.2643-I.84 I 5607.

53 These proposals for 'modifications' stem from the Labour Party and SP, both of them in political opposition to the ruling party. It is an election year in $202 \mathrm{I}$. 
Bramness, J. G. (201 8). Hva er avhengighet. Oslo:

Universitetsforlaget.

Christie, N. (I968). Langhåret livsstil. Nordisk Tidsskrift for Kriminalvidenskab 55. (I).

Christie, N., \& Kettil, B. (I985). Den gode fiende. Narkotikapolitikk i Norden. Oslo: Universitetsforlaget.

Cohen, S. (1972/2009). Folk devils and moral panics. The creation of mods and rockers. London: Routledge [2009].

Dagsavisen (20I4). 'Politiet skal ikke løpe etter slitne narkomane.' https://www.dagsavisen.no/nyheter/innenriks/politiet-skal-ikke -lope-etter-slitne-narkomane-I.2780 6.

Eidet, T. (2019). Politiets etterretningsregister Indicia: en upålitelig ryktebørs eller en pålitelig kilde til det kunnskapsbaserte politiarbeidet? Master i etterforskning, Politihøgskolen, Oslo.

Ellingsen, D. (200I). Kriminalitet og rettsvesen. Statistisk sentralbyrå. Oslo.

Flaatten, S. (20I4). 'Skaane de angrende og bekjæmpe de trodsige' Straffeloven av I902 og den positivistiske straffeutmåling. In S. Flaatten and G. Heivoll (Eds.), Straff, Lov Historie. Historiske perspektiver på straffeloven av I902. Oslo: Akademisk Publishing.

Franko, K. (2020). The crimigrant other. Migration and penal power. London: Routledge.

Fyfe, R. N., Gundhus, H.O.I. \& Rønn, K.V. (2018). Moral Issues in Intelligence-Led Policing. Oxon: Routledge.

Granér, R. (2004). Patrullerande polisers yrkeskultur. Lund University disertations, Lund.

Hari, J. (2OI 5). Chasing the scream. The first and last days of the war on drugs. London: Bloomsbury.

Haslund, U. (I999). Kraftig økning i narkotikaforbrytelser, i: Samfunnsspeilet nr. I 2000, https://www.ssb.no/sosiale -forhold-og-kriminalitet/artikler-og-publikasjoner/kraftig-okning -i-narkoforbrytelser. 
Hauge, R. (2008). Straff for narkotikabruk - kan det begrunnes? Publisert på Forebygging.no. http://www.forebygging.no /Kronikker/20IO-2008/Straff-for-narkotikabruk-kan-det -begrunnes/.

Hauge, R. (2009). Rus og rusmidler giennom tidene. Oslo: Universitetsforlaget.

Hauge, R. (20 I 5 ). Cannabispolitikken i støpeskjeden. In L. Korsell, P. Larsson \& J.G. Christophersen (Eds.), Ekstraordincere tider. Festskrift til Per Ole Johansen 70 år. Oslo: Novus forlag.

Hughes, C. E., \& Stevens, A. (201 2). A resounding success or a disastrous failure: Re-examining the interpretation of evidence on the Portuguese decriminalisation of illicit drugs. Drug and Alcohol Review, 3 I.(5).

Jensen, E. (2OI 5). På innsiden. Historien om mitt politiliv. Oslo: Kagge forlag.

Larsson, P. (20I I). Narkotikakriminalitet: trusselbilder og realiteter. Rus og samfunn nr. 4, $20 \mathrm{II}$.

Larsson, P. (20I4). Å danse med djevelen: utradisjonelle metoder i narkotikafeltet. Nordisk Samarbeidsråd for Kriminologi publication Vol. 56.

Larsson, P. (2015). Politistrategier mot narkotika. In H. Giertsen \& H. Gunnlaugsson (Eds.), Drugs: What is the problem and how do we perceive it? Policies on drugs in Nordic countries. NSfK (Nordiska Samarbetsrådet för Kriminologi) working group report. Aarhus.

Larsson, P. (201 8). Organisert kriminalitet. Oslo: Pax.

Larsson, P. Kriminologi i ett nøtteskall, Unpublished manuscript.

Lie, E. M. (2020). Politiets bekymringssamtale. https://www.nubu .no/utgave-6/politiets-bekymringssamtale-article3 198 -2580 .html.

Lien, M. I. \& Larsen, Y. (nd.). Flinkiser og 'dropouts'. Erfaringer med ungdom på frivillig ruskontrakt, KoRus Øst, Report._PUB_ Flinkiser_og_dropouts_orig.pdf (rus-ost.no).

Lind, B. B. (1974). Narkotikakonflikten. Stoffbruk og myndighetskontroll. Oslo: Gyldendal. 
Lomell, H. Mork. (201 8). Fra 'Arbeidsmengde' til 'Resultat': Oslopolitiets egen presentasjon av kriminalstatistikk I950-2008. Nordisk Tidsskrift for Kriminalvidenskab, I05(2), I33-I 53.

MacCoun, R. J., \& Reuter, P. (200I). Drug war heresies. Learning from other vices, times \& places. Cambridge: Cambridge University Press.

Mathiesen, T. (1975). Løsgjengerkrigen. Oslo: Pax.

Møller, K. (20I I). Kontrolregimer og narkotikapolitik: Hvordan balanceres borgernes velbefindende og selvbestemmelse? In V.A. Frank\& H. Dahl (Eds.), Illegale rusmidler og kriminalitet. Århus: Aarhus Universitetsforlag. I45-I 68.

Murji, K. (1998). Policing drugs. Aldershot: Ashgate.

Narkotikautløste dødsfall 2020. Oslo: FHI. Folhelseinstituttet.

Nasjonal trusselvurdering. (2020). PST. https://pst.no/alle-artikler /trusselvurderinger/nasjonal-trusselvurdering-2020/.

NOU I997: I 5. Metodeutvalget. Etterforskningsmetoder for bekjempelse av kriminalitet, Delinnstilling II, Justis- og politide partementet, Oslo.

NOU 2002:4. Ny Straffelov - Straffelovskommisjonens delutrening VII. Justis og politidepartementet, Oslo. NOU 2002: $0_{4}^{-}$ regjeringen.no.

NOU 2009: I 5. Skjult informasjon - åpen kontroll -

Metodekontrollutvalgets evaluering av lovgivningen om politiets bruk av skjulte tvangsmidler og behandling av informasjon $i$ straffesaker, Justis- og politidepartementet, Oslo.

NOU 2019: 26. Rusreform - fra straff til hjelp. Helse- og omsorgsdepartmentet, Oslo. https://www.regjeringen.no/conten

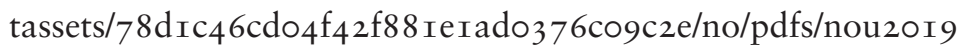
20190026000dddpdfs.pdf.

Nutt, D. (2012). Drugs without the hot air. Cambridge: Cambridge UIT.

Olsen, H. (2020). Narkotikapolitikk og skadereduksjon Dilemmaer $i$ politiarbeid, rusbehandling og sprøyterom, Phd. dissertation, Institutt for kriminologi og rettssosiologi, Juridisk fakultet, Universitetet i Oslo. 
Ot. prp. nr. 5. (I97I-72) Om lov om endringer i den alminnelige straffelov 22 mai I902.nr Io.

Paoli, L. A., Greenfield, V. A., \& and Reuter, P. (2009). The world heroin market. Can supply be cut? Oxford: Oxford University Press.

Pedersen, W. (2020). Krigen mot narkotika er avblåst, Morgenbladet 3. januar. https://morgenbladet.no/boker/2020/oI/krigen-mot -narkotika-avblast.

Politidirektoratet. (2010). Politiets bekjempelse av narkotikakrimi-

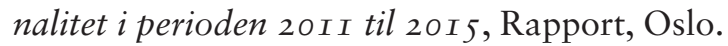

Prop. 92 L (2020-202I) Proposisjon til Stortinget (forslag til lovvedtak). Endringer i helse- og omsorgstjenesteloven og straffeloven m.m. (rusreform - opphevelse av straffansvar m.m.) Prop. 92 L (2020-202I) (regjeringen.no). https://www.regjerin gen.no/no/aktuelt/utvalg-skal-forberede-ny-rusreform/id2 $594838 \%$.

Reiner, R. (20I0). The politics of the police. Oxford: Oxford University Press.

Sheptycki, J.W.E. (2000). Issues in transnational policing. London and New York: Routledge.

Skretting, A. (2013). Konseptualisering av narkotika $i$ sentrale offentlige dokumenter, Forebygging.no, http://www.forebygging .no/Artikler/20I4-20 I 2/Konseptualisering-av-narkotika -i-sentrale-offentlige-dokumenter/.

Stene, R. J. (2003). Siktede of narkotikalovbrudd, I992-200I. Narkotika, kontroll og bruk Samfunnsspeilet, I.

Stortingsmeldingen om narkotika (St.meld nr. 66. (I975-76)).

Tabell 4 Lovbrudd anmeldt, etter type lovbrudd. I99I-200 I (ssb.no).

Träskman, P. O. (2OI 2). The dragon's egg. Drugs-related crime control. In R. Bragadóttir (Ed.), Nordic Criminology in 50 years. Scandinavian Council, Report, pp. I I9-I 50, Reykjavik.

Wathne, C. T. (2OI 5). Som å bli fremmed $i$ eget hus. Ph-d avhandling Institutt for kriminologi og rettssosiologi, Universitetet i Oslo. 
Woods, N. (2017). Good cop, bad war. UK: Ebury Press.

Zaitch, D. (2002). Trafficking cocaine. Colombian drug entrepreneurs in the Netherlands. Hague: Kluwer Law International. 